\title{
Panretinal photocoagulation versus intravitreal injection retreatment pain in high-risk proliferative diabetic retinopathy
}

\author{
Dor em panfotocogulação retiniana versus injeção intravítrea em pacientes com \\ retinopatia diabética proliferativa de alto risco
}

Célia Regina Farias de Araújo lucena ${ }^{1}$, José Afonso Ramos Filho ${ }^{1}$, André Márcio Vieira Messias ${ }^{1}$, José Aparecido da Silva², Felipe Piacentini Paes de Almeida ${ }^{1}$, Ingrid Ursula Scott ${ }^{3}$, Jefferson Augusto Santana Ribeiro ${ }^{1,4}$, Rodrigo Jorge ${ }^{1}$

\begin{abstract}
Purpose: To compare pain related to intravitreal injection and panretinal photocoagulation in the management of patients with high-risk proliferative diabetic retinopathy.

Methods: Prospective study including patients with high-risk proliferative diabetic retinopathy and no prior laser treatment randomly assigned to receive panretinal photocoagulation (PRP group) or panretinal photocoagulation plus intravitreal ranibizumab (PRPplus group). In all patients, panretinal photocoagulation was administered in two sessions (weeks 0 and 2), and intravitreal ranibizumab was administered at the end of the first laser session in the PRPplus group. Retreatment was performed at weeks 16 and 32 if active new vessels were detected at fluorescein angiography. Patients in the PRPplus group received intravitreal ranibizumab and patients in the PRP group received 500- $\mu \mathrm{m}$ additional spots per quadrant of active new vessels. After the end of retreatment, a 100-degree Visual Analog Scale was used for pain score estimation. The patient was asked about the intensity of pain during the whole procedure (retinal photocoagulation session or intravitreal ranibizumab injection). Statistics for pain score comparison were performed using a non-parametric test (Wilcoxon rank sums).

Results: Seventeen patients from PRPplus and 14 from PRP group were evaluated for pain scores. There were no significant differences between both groups regarding gender, glycosylated hemoglobin and disease duration. Mean intravitreal injection pain $( \pm$ SEM) was $4.7 \pm 2.1$ and was significantly lower $(p<0.0001)$ than mean panretinal photocoagulation pain $(60.8 \pm 7.8)$. Twelve out of 17 patients from the PRPplus group referred intensity pain score of zero, while the minimal score found in PRP group was found in one patient with 10.5.

Conclusion: In patients with high-risk proliferative diabetic retinopathy who needed retreatment for persistent new vessels, there was more comfort for the patient when retreatment was performed with an intravitreal injection in comparison with retinal photocoagulation. Further larger studies are necessary to confirm our preliminary findings.
\end{abstract}

Keywords: Pain; Intravitreal injections; Diabetic retinopathy; Light coagulation; Vascular endothelial growth factor A

\section{RESUMO}

Objetivo: Comparar a dor relacionada à injeção intravitrea e panfotocoagulação no tratamento de pacientes com retinopatia diabética proliferativa de alto risco.

Métodos: Estudo prospectivo incluindo pacientes com retinopatia diabética proliferativa de alto risco e nenhum tratamento a laser prévio aleatoriamente designados para receber panfotocoagulação retiniana (grupo PRP) ou panfotocoagulação e ranibizumabe intravítreo (grupo PRPplus). Em todos os pacientes, a panfotocoagulação foi administrada em duas sessões (semanas 0 e 2), e ranibizumabe intravítreo foi administrado no final da primeira sessão de laser no grupo PRPplus. Retratamento fol realizado nas semanas 16 e 32 se neovasos ativos fossem detectados na angiofluoresceinografia, utilizando ranibizumabe intravítreo no grupo PRPplus e laser adicional grupo PRP. Após o fim do retratamento, uma Escala Analógica Visual de 100-unidades foi utilizada para a estimativa da pontuação da dor. O paciente foi questionado sobre a intensidade da dor durante to do o procedimento (sessão de fotocoagulação de retina ou injeção intravitrea de ranibizumabe). A comparação dos índices de dor foi realizada utilizando um teste não-paramétrico (Wilcoxon rank sums).

Resultados: Dezessete pacientes do grupo PRPpluse 14 do grupo PRP foram avaliados para os índices de dor. Não houve diferenças significativas entre os dois grupos quanto ao sexo, hemoglobina glicosilada e duração da doença. A média de dor da injeção intravitrea ( \pm SEM) foi $4,7 \pm 2,1$, significativamente menor $(p<0,0001)$ do que a dor média da panfotocoagulação $(60,8 \pm 7,8)$. Doze dos 17 pacientes do grupo PRPplus referiram pontuação de intensidade da dor zero, enquanto que o índice mínimo no grupo PRP foi encontrado em um paciente com 10,5.

Conclusão: Em pacientes com retinopatia diabética proliferativa de alto risco que necessitaram de retratamento por neovasos persistentes, houve mais conforto para o paciente quando o retratamento foi realizado com uma injeção intravitrea em comparação com fotocoagulação da retina. Estudos posteriores são necessários para confirmar nossos achados preliminares.

Descritores: Dor; Injeções intravitreas; Retinopatia diabética; Fotocoagulação; Fator A de crescimento endotélio vascular
Submitted for publication: July 18, 2012

Accepted for publication: November 21, 2012

Study carried out at School of Medicine of Ribeirão Preto, Universidade de São Paulo.

Physician, Department of Ophthalmology, Ribeirão Preto School of Medicine, Universidade de São Paulo - USP - Ribeirão Preto, SP, Brazil;

Physician, Department of Psychology, Faculty of Philosophy, Sciences and Literature, Universidade de São Paulo - USP - São Paulo, SP, Brazil;

Physician, Departments of Ophthalmology and Public Health Sciences, Penn State College of Medicine, Hershey, PA, USA;

Physician, School of Health Sciences, Universidade Estadual do Amazonas - UEA - Manaus, AM, Brazil.
Funding: Supported by CNPq: Grant number: 306692/2008-2.

Disclosure of potential conflicts of interest: C.R.F.A.Lucena, None; J.A.Ramos Filho, None A.M.V.Messias, None; J.A.Silva, None; F.P.P.Almeida, None; I.U.Scott, None; J.A.S.Ribeiro, None R.Jorge, None.

Corresponding author: Rodrigo Jorge. Divisão de Oftalmologia, Faculdade de Medicina de Ribeirão Preto. Avenida Bandeirantes, 3900 - Ribeirão Preto (SP) - 14049-900 - Brazil

E-mail: rjorge@fmrp.usp.br

The present study was part of a master degree thesis from C. R. Lucena.

Review Board approval: 11976/2008.

Clinical Trial register: NCT01009021. 


\section{INTRODUCTION}

Retinal new vessels (NV) represent an important risk factor for severe vision loss in patients with diabetes mellitus ${ }^{(1)}$. About $60 \%$ of patients with proliferative diabetic retinopathy (PDR) respond to panretinal photocoagulation (PRP) with regression of neovascularization within 3 months ${ }^{(2)}$. However, many patients require additional laser treatment, and $4.5 \%$ ultimately require pars plana vitrectomy despite PRP(3).

Besides additional laser photocoagulation, intravitreal injection of anti-vascular endothelial growth factor (VEGF) agents have become an interesting alternative for new vessels regression ${ }^{(4,5)}$. However, both procedures (PRP and injection) may induce discomfort and pain. Pain regarding PRP treatment is a well-recognized concern and may even prevent its completion ${ }^{(6)}$, while pain regarding intravitreal injection may disturb patient compliance and peribulbar block may be necessary for uncooperative patients ${ }^{(7)}$. Since intravitreal injection has become a trendy alternative therapeutic strategy and PRP is the standard of care for high-risk PDR, we decided to compare pain related to both procedures in the management of patients with PDR.

\section{METHODS}

The study protocol adhered to the tenets of the Declaration of Helsinki and was approved by the local Institutional Review Board, and all patients gave written informed consent before entering the study.

This is a prospective, open label, randomized study in which two groups of diabetic patients were followed ${ }^{(5)}$. Between February 2009 and December 2009, all patients evaluated at the Retina and Vitreous Section of the Department of Ophthalmology, School of Medicine of Ribeirão Preto, who presented with high-risk PDR and had not received any prior retinal laser treatment were invited to participate in the study.

Patients were included if they had high-risk PDR, according to Early Treatment Diabetic Retinopathy Study (ETDRS) guidelines ${ }^{(1,8)}$, as follows: 1) presence of NV at the disc (NVD) greater than ETDRS standard photograph 10A, or; 2) presence of NVD associated with vitreous or pre-retinal hemorrhage, or; 3) NV elsewhere (NVE) covering more than a half disc area associated with vitreous or pre-retinal hemorrhage. Exclusion criteria included: 1) history of prior laser treatment or vitrectomy in the study eye; 2) history of thromboembolic event (including myocardial infarction or cerebral vascular accident); 3) major surgery within the prior 6 months or planned within the next 28 days; 4) uncontrolled hypertension (according to guidelines of the seventh report of the joint National Committee on Prevention, Detection, Evaluation, and Treatment of High Blood Pressure [JNC-7] $)^{(9)}$; 5) known coagulation abnormalities or current use of anticoagulation medication other than aspirin; or 6) any condition affecting documentation or follow-up.

During the study enrollment period, high-risk PDR was identified in one eye of 5 patients and in both eyes of 35 patients based on clinical examination and confirmed on fluorescein angiography. At baseline, each patient received a detailed ophthalmologic examination including measurement of the logarithm of the minimum angle of resolution (logMAR) ETDRS and best corrected visual acuity (BCVA) according to a standardized refraction protocol (using modified ETDRS charts 1, 2, and R), as well as applanation tonometry, dilated slit lamp biomicroscopic examination (including grading of lenticular opacities using the Lens Opacities Classification System III)(10), and binocular indirect fundoscopic examination. Digital red free fundus photography and fluorescein angiography were performed using two fundus camera systems (HRA-OCT, Heidelberg, Germany/TRC-50IA/ IMAGEnet; Topcon, Tokyo, Japan).

All patients received PRP, which was performed in two sessions (at week 0 and week 2) according to ETDRS guidelines ${ }^{(11)}$. Six hundred to eight hundred $500 \mu \mathrm{m}$ spots were performed per session, at the discretion of the treating investigator. If patients had clinically significant macular edema ${ }^{(12)}$ macular focal/grid laser was performed during the first PRP session. Patients could be retreated with focal/grid laser at the 16 and 32-week study visits. If both eyes were eligible for the study, the eye with best visual acuity was included.

Patients were enrolled in groups of two. The technician was asked to pick up one of two identical opaque envelopes, one containing the designation for PRP, whereas the other contained the designation for PRP/intravitreal ranibizumab injection (IVR) treatment. The second patient was automatically assigned with the second envelope. For the 20 eyes selected to receive the combined treatment (PRP plus intravitreal ranibizumab), one intravitreal injection of $0.5 \mathrm{mg}(0.05 \mathrm{ml})$ of ranibizumab was performed approximately 60 minutes after the completion of the first PRP session (week 0 ) by a single retinal specialist. Ranibizumab was injected into the vitreous cavity via a 29 gauge needle inserted through the inferotemporal pars plana 3.0 - $3.5 \mathrm{~mm}$ posterior to the limbus using topical proparacaine drops under sterile conditions (eyelid speculum and povidone-iodine) ${ }^{(13)}$. Patients were instructed to instill one drop of $0.3 \%$ ciprofloxacin into the injected eye four times daily for 1 week after the procedure.

Retreatment was performed at weeks 16 and 32 if active new vessels were detected at fluorescein angiography. Patients in the PRPplus group received IVR and patients in the PRP group received 500-um additional spots per quadrant of active new vessels.

Fifteen minutes after the end of retreatment (PRP session or retreatment IVR injection), a masked examiner used a 100-degree Visual Analog Scale (VAS) for pain score estimation ${ }^{(7)}$. The numbers of the scale were visible only on the examiner's side, so that patients could not choose the same number to guide pain scores. Prior to rating level of pain, each patient was asked to slide the marker along the entire scale, with the aid of the examiner. At point 0 , the examiner clarified to the patient that this point of the scale represented "no pain at all"; at point 100, the examiner clarified to the patient that this point of the scale represented "the most intense pain one could ever feel". The patient was asked about the intensity of pain during the whole procedure (PRP session or IVR injection). Statistics for pain score comparison were performed using a non-parametric test (Wilcoxon rank sums).

\section{RESULTS}

Seventeen patients from the PRP plus patients and 16 patients from the PRP groups completed the 16-week visit, but 17 patients from PRPplus and 14 from PRP were evaluated for pain scores. Patients' demographics are summarized in table 1. Mean age of PRP patients was significantly higher than PRPplus patients; there were no significant differences between both groups regarding gender, glycosylated hemoglobin (HbA1c) and disease duration. Mean \pm SD age (years) was $63.5 \pm 8.9$ and $51.1 \pm 11.3(p=0.0018)$; mean \pm SD $\mathrm{HbA} 1 \mathrm{c}(\%)$ was $9.3 \pm 1.1$ and $9.1 \pm 0.8(\mathrm{p}=0.5391)$; and mean \pm SD disease duration (years) was $12.9 \pm 8.8$ and $14.7 \pm 6.9(p=0.5326)$ for PRP and PRPplus respectively. Mean IVR pain ( \pm SEM) was $4.7 \pm 2.1$ and was significantly lower $(p<0.0001)$ than mean PRP pain $(60.8 \pm 7.8)$. Twelve out of 17 patients from the PRPplus group referred intensity pain score of zero, meaning that they had no pain at all during intravitreal injection, while the minimal score found in PRP group was found in one patient with 10.5, but no other patient in this group had score under 30 . Figure 1 shows the distribution of intensity pain scores in both groups; there was a statistically significant difference between groups ( $P<0.0001$; Wilcoxon).

\section{DISCUSSION}

Despite the difference in age between groups, that would have favored lower scores in PRP group (since older patients trend to feel less pain) ${ }^{(14)}$, the present results suggest that an intravitreal injection 
Table 1. Patient demographics

\begin{tabular}{lccc}
\hline & PRP & PRPplus & P \\
\hline Age (mean \pm SD; in years) & $63.5 \pm 8.9$ & $51.1 \pm 11.3$ & 0.0018 (t-Test) \\
Gender (Male/Female) & $9 / 5$ & $10 / 7$ & $\begin{array}{c}0.7557 \\
\text { (Likelihood Ratio) }\end{array}$ \\
Race (Black/Hispanic/Caucasian) & $2 / 7 / 5$ & $2 / 8 / 7$ & $\begin{array}{c}0.9461 \\
\text { (Likelihood Ratio) }\end{array}$ \\
$\begin{array}{l}\text { Duration of diabetes } \\
\text { (mean } \pm \text { SD; in years) }\end{array}$ & $12.9 \pm 8.8$ & $14.7 \pm 6.9$ & 0.5326 (t-Test) \\
HbA1c (mean \pm SD) & $9.3 \pm 1.1$ & $9.1 \pm 0.8$ & 0.5391 (t-Test) \\
\hline
\end{tabular}

$\mathrm{HbA} 1 \mathrm{c}=$ glycosylated hemoglobin; $\mathrm{PRP}=$ panretinal photocoagulation; PRPplus= panretinal photocoagulation and intravitreal injection of ranibizumab; $\mathrm{SD}=$ standard deviation.

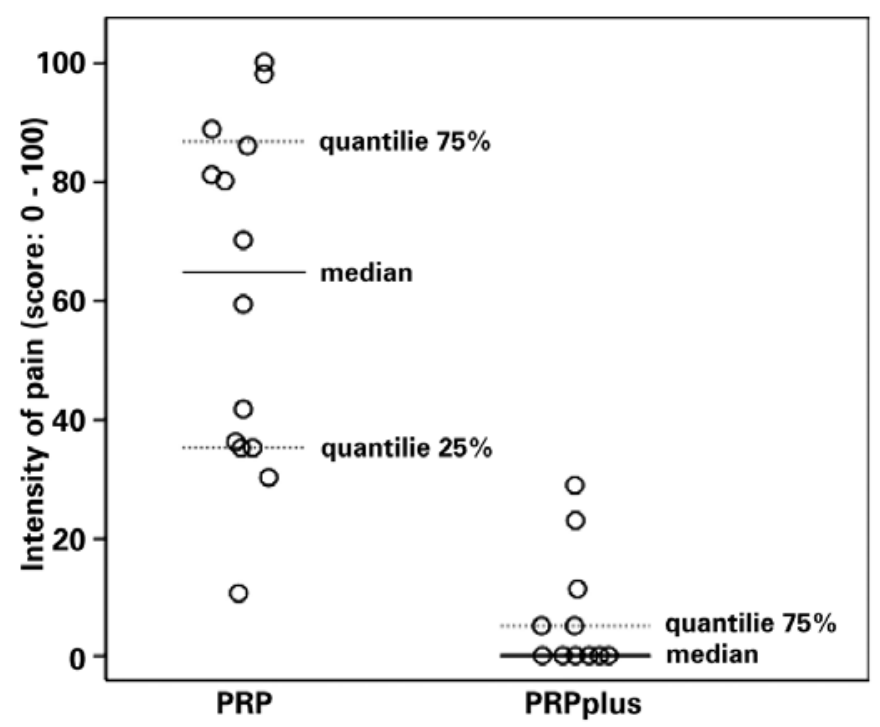

Figure 1.Intensity of pain score distribution on PRP and PRPplus groups. Horizontal lines represent groups'medians and dashed lines are the $25 \%$ and $75 \%$ quantilies. Statistically significant difference was found between groups $(\mathrm{P}<0.0001$; Wilcoxon).

is less painful than a PRP session for diabetic patients with high-risk PDR. In fact, pain score associated with intravitreal injections of anti-VEGF agents in patients with diabetic retinopathy and neovascular age-related macular degeneration (ARMD) ranges from 0 to $22^{(7)}$, while pain level associated with a PRP session ranges from 10 to $90^{(6)}$. This difference may be explained by the longer pain stimulus during a PRP session. Another hypothesis is that there may be direct stimulation of the long ciliary nerves during a PRP session (especially if laser applied in the retina periphery at 3 and 9 o'clock meridians) usually merely under topical anesthesia for PRP contact lens positioning, while during intravitreal injections there would be needle conjunctival and uveal nociceptors stimulation, usually partially blocked by topical anesthesia ${ }^{(7)}$.

\section{CONCLUSION}

In addition to the beneficial effects regarding BCVA and new vessels regression of PRPplus ranibizumab in comparison to PRP alone for high-risk PDR treatment reported elsewhere, there is also more comfort for the patient when retreatment is performed with an intravitreal injection. Further larger studies are necessary to confirm our preliminary findings.

\section{REFERENCES}

1. Fundus photographic risk factors for progression of diabetic retinopathy. ETDRS report number 12. Early Treatment Diabetic Retinopathy Study Research Group. Ophthalmology. 1991;98(5 Suppl):823-33.

2. Vander JF, Duker JS, Benson WE, Brown GC, McNamara JA, Rosenstein RB. Long-term stability and visual outcome after favorable initial response of proliferative diabetic retinopathy to panretinal photocoagulation. Ophthalmology. 1991;98(10):1575-9.

3. Flynn HW Jr, Chew EY, Simons BD, Barton FB, Remaley NA, Ferris FL 3rd. Pars plana vitrectomy in the Early Treatment Diabetic Retinopathy Study. ETDRS report number 17. The Early Treatment Diabetic Retinopathy Study Research Group. Ophthalmology. 1992;99(9):1351-7.

4. Jorge R, Oliveira RS, Messias A, Almeida FP, Strambe ML, Costa RA, et al. Ranibizumab for retinal neovascularization. Ophthalmology [Internet]. 2011 [cited 2012 Jan 21];118(5):1004. Available from: http://www.sciencedirect.com/science/article/pii/ S0161642010013783

5. Ramos-Filho JA, Messias A, Almeida FP, Ribeiro JA, Costa RA, Scott IU, et al. Panretinal photocoagulation (PRP) versus PRP Plus intravitreal ranibizumab for high-risk proliferative diabetic retinopathy. Acta Ophthalmol Scand [Internet]. 2011 [cited 2012 Jun 21];89(7):e567-72. Available from: http://onlinelibrary.wiley.com/doi/10.1111/j.17553768.2011.02184.x/full

6. De Faria Rodrigues A, Messias AM, Da Silva JA, Ribeiro JA, Jorge R, Scott IU. Diclofenac for panretinal photocoagulation pain. Ophthalmology [Internet]. 2010[cited 2012 Jun 21];117(12):2441.e1-3. Available from: http://www.sciencedirect.com/science/article/ pii/S0161642010006093

7. Cintra LP, Lucena LR, Da Silva JA, Costa RA, Scott IU, Jorge R. Comparative study of analgesic effectiveness using three different anesthetic techniques for intravitreal injection of bevacizumab. Ophthalmic Surg Lasers Imaging. 2009;40(1):13-8.

8. Four risk factors for severe visual loss in diabetic retinopathy. The third report from the diabetic retinopathy study. The Diabetic Retinopathy Study Research Group. Arch Ophthalmol [Internet]. 1979[cited 2010 Jun 12];97(4):654-5. Available from: http:// archopht.jamanetwork.com/article.aspx?articleid=632929

9. Chobanian AV, Bakris GL, Black HR, Cushman WC, Green LA, Izzo JL Jr, Jones DW, Materson BJ, Oparil S, Wright JT Jr, Roccella EJ; National Heart, Lung, and Blood Institute Joint National Committee on Prevention, Detection, Evaluation, and Treatment of High Blood Pressure; National High Blood Pressure Education Program Coordinating Committee. The Seventh Report of the Joint National Committee on Prevention, Detection, Evaluation, and Treatment of High Blood Pressure: the JNC 7 report. JAMA [Internet]. 2003 [cited 2010 Jun 21];289(19):2560-72. Erratum in: JAMA. 2003;290(2):197. Comment in: JAMA. 2003;290(10):1313; author reply 1314-5; JAMA. 2003;289(19):2573-5; JAMA. 2003;290(10):1312; author reply 1314-5; JAMA. 2003; 290(10):1313; author reply 1314-5. Available from: http://jama.jamanetwork.com/article.aspx?articleid=196589

10. Chylack LT Jr, Wolfe JK, Singer DM, Leske MC, Bullimore MA, Bailey IL, et al. The lens opacities classification system III. The Longitudinal Study of Cataract Study Group. Arch Ophthalmol [Internet]. 1993[cited 2010 Oct 12];111(6):831-6. http://archopht. jamanetwork.com/article.aspx?articleid $=640261$

11. Techniques for scatter and local photocoagulation treatment of diabetic retinopathy: Early Treatment Diabetic Retinopathy Study Report n. 3. The Early Treatment Diabetic Retinopathy Study Research Group. Int Ophthalmol Clin. 1987;27(4):254-64.

12. Photocoagulation for diabetic macular edema. Early Treatment Diabetic Retinopathy Study report number 1. Early Treatment Diabetic Retinopathy Study Research Group. Arch Ophthalmol [Internet]. 1985[cited 2010 Apr 23];103(12):1796-806.Available from: http://archopht.jamanetwork.com/article.aspx?articleid=635820

13. Ribeiro JA, Messias AM, Scott IU, Jorge R. Alternative technique for reducing compound waste during intravitreal injections. Arq Bras Oftalmol [Internet]. 2009 [cited 2010 Dec 21];72(5):641-4. Available from: http://www.scielo.br/pdf/abo/v72n5/08.pdf

14. Catananti C, Gambassi G. Pain assessment in the elderly. Surg Oncol [Internet]. 2010[cited 2011 Sep 21];19(3):140-8.Available from: http://www.sciencedirect.com/ science/article/pii/S0960740409001261 